\title{
Povezanost sociodemografskih varijabla i glazbenih preferencija učenika osnovne glazbene škole
}

Jasna Šulentić Begić*

jsulentic-begic@aukos.hr

https://orcid.org/0000-0003-4838-0324

Amir Begićs*

abegic@aukos.hr

https://orcid.org/0000-0003-2152-9563

Marija Bilićc*\%

marijabilicv@gmail.com

https://orcid.org/0000-0003-4396-2990 https://doi.org/10.31192/np.19.2.14

UDK: [373.3:78]:[7.011:78]

[303.423:373.3-057.87]:78

Izvorni znanstveni rad / Original scientific

paper

Primljeno: 23. prosinca 2020.

Prihvaćeno: 26. travnja 2021.

Preferencija se definira kao afektivno stanje niskog intenziteta, a to bi u odnosu na područje glazbe podrazumijevalo glazbu nekog glazbenika ili neki glazbeni stil ili konkretnu skladbu koju pojedinac voli i odabire za slušanje. Glazbena preferencija je u pravilu spontana reakcija i ne uključuje nužno estetske kriterije, tj. kognitivne procese. Čimbenike koji su povezani s glazbenim preferencijama može se kategorizirati kao unutarnje (npr. karakteristike glazbe) $i$ vanjske (npr. dob, spol, osobnost, društveni utjecaj, glazbeno obrazovanje, društveni identitet $i$ dr.). U okviru rada provedeno je istraživanje čiji je cilj bio utvrditi povezanost sociodemografskih varijabla (spol učenika, mjesto stanovanja i bavljenje njihovih roditelja glazbom) i glazbenih preferencija učenika osnovne glazbene škole. Istraživanje je provedeno online anketiranjem u travnju 2020. godine u sedam osnovnih glazbenih škola u Republici Hrvatskoj. U istraživanju je sudjelovalo 95 učenika petih $i$ šestih razreda osnovnih glazbenih škola. Primjenom hi-kvadrat testa utvrđeno je postojanje statistički značajnih razlika u preferencijama ispitanika prema rocku, metalu, turbofolku, umjetničkoj glazbi, pop i elektroničkoj glazbi s obzirom na spol, mjesto stanovanja i glazbenu tradiciju u obitelji.

Ključne riječi: glazbene preferencije, nastava glazbe, osnovna glazbena škola.

* Izv. prof. dr. sc. Jasna Šulentić Begić, Sveučilište J. J. Strossmayera u Osijeku, Akademija za umjetnost i kulturu u Osijeku, Kralja Petra Svačića 1/F, HR-31000 Osijek.

** Doc. dr. sc. Amir Begić, Sveučilište J. J. Strossmayera u Osijeku, Akademija za umjetnost i kulturu u Osijeku, Kralja Petra Svačića 1/F, HR-31000 Osijek.

**:* Marija Bilić, mag. mus., Glazbena škola Muzički Atelje, Harambašićeva 14, HR-10000 Zagreb. 


\section{Uvod}

Na popularnost neke glazbe najviše utječe činjenica koliko je često imamo priliku čuti. Najčešće smo izloženi glazbi koja se reproducira putem medija kao što su radio, televizija i internet te je takva glazba danas i najpopularnija. Da je to tako, očit primjer je umjetnička glazba ${ }^{1}$ koja se manje sluša jer se rjeđe reproducira putem najpopularnijih medija. ${ }^{2}$ Danas je glazba sveprisutna, tj. u prodavaonicama, na aerodromima, željezničkim stanicama i sportskim natjecanjima, dio je filmova i televizijskih programa, proizvođači je koriste za reklamiranje proizvoda dok je studiji za jogu, masažu i vježbanje koriste za opuštanje ili podizanje raspoloženja. Uz sve ove pozadinske upotrebe glazbe mnogi ipak biraju glazbu prema svom izboru, ${ }^{3} \mathrm{tj}$. u skladu s glazbenim preferencijama i glazbenim ukusom.

Preferencija se definira kao afektivno stanje niskog intenziteta, a to bi u odnosu na područje glazbe podrazumijevalo glazbu nekog glazbenika ili neki glazbeni stil ${ }^{4}$ ili konkretnu skladbu ${ }^{5}$ koju pojedinac voli i odabire za slušanje. Lawendowski smatra da je glazbena preferencija u pravilu spontana reakcija i ne uključuje nužno estetske kriterije, tj. kognitivne procese. ${ }^{6}$ Za razliku od glazbene preferencije glazbeni ukus su sveukupne preferencije pojedinca tijekom duljeg razdoblja ${ }^{7}$ podrazumijeva estetski kriterij.

Glazbena preferencija ima dvije dimenzije: vrstu i utjecaj. Vrsta se odnosi na pitanje koje glazbeno djelo, odnosno glazbeni stil osoba najviše voli, dok se utjecaj odnosi na pitanje zašto netko voli neko glazbeno djelo, odnosno glazbeni stil. Glazbena psihologija uglavnom se usmjerila na ispitivanje vrste glazbene preferencije, no ne i utjecaja. ${ }^{8}$ Glazbene preferencije povezane su is

${ }^{1}$ U radu se koristi pojam umjetnička glazba, a ne klasična glazba. Izraz klasična glazba u literaturi se koristi za glazbu nastalu u doba bečke klasike - klasicizma. Također, taj se izraz koristi i za glazbu kojoj se uobičajeno pripisuje trajna svjetska povijesna vrijednost. Za potonje se $u$ literaturi koristi i izraz ozbiljna glazba. U ovom radu, kao sinonim koji obuhvaća oba značenja pojma klasična glazba te pojam ozbiljna glazba - koristi se termin umjetnička glazba.

2 Usp. Chanel K. MEYERS, Influences on Music Preference Formation, PURE Insights, 1 (2012) 31-34, 33.

${ }^{3}$ Usp. David HURON, Is music an evolutionary adaptation?, u: Isabelle PERETZ, Robert J. ZATORRE (ur.), The cognitive neuroscience of music, Oxford, Oxford University Press, 2003, 5775,58 .

${ }^{4}$ Usp. Durgesh UPADHYAY, Ridhima SHUKLA, Aheli CHAKRABORTY, Factor Structure of Music Preference Scale and Its Relation to Personality, Journal of Indian Academy of Applied Psychology, 43 (2016) 1, 104-113, 105.

${ }^{5}$ Usp. David J. HARGREAVES, Adrian C. NORTH, Mark TARRANT, Musical preference and taste in childhood and adolescence, u: Gary MCPHERSON (ur.), The child as musician: A handbook of musical development, Oxford, Oxford University Press, 2006, 135-154, 135.

${ }^{6}$ Usp. Rafał LAWENDOWSKI, Temporal Stability of Music Preferences as an Indicator of Their Underlying Conditionings, u: Geoff LUCK, Olivier BRABANT (ur.), Proceedings of the $3^{\text {rd }}$ International Conference on Music \& Emotion (ICME3), Jyväskylä, University of Jyväskylä, Department of Music, 2013, 24-44, 32.

7 Usp. Hargreaves i sur., Musical preference and taste..., 135.

${ }^{8}$ Usp. Upadhyay i sur., Factor Structure of Music Preference..., 105. 
ulogama koje glazba ima za pojedinca, a one mogu biti u svrsi reguliranja emocija i raspoloženja, podizanja samopouzdanja te poticanja socijalne povezanosti. ${ }^{9}$ Naime, ljudi preferiraju glazbu koja im pomaže u postizanju nekog cilja, tj. imaju predodžbu koja glazba je prikladna za različite okolnosti slušanja. ${ }^{10}$ Tako osobe, kada su u situacijama koje izazivaju uzbuđenje, kao npr. vožnja u prometu, preferiraju opuštajuću glazbu, dok u ugodnim situacijama kao što je npr. vježbanje, preferiraju poticajnu glazbu..$^{11}$ Utvrđeno je da glazbeno obrazovaniji ljudi više koriste glazbu za postizanje ciljeva, za razliku od onih koji nemaju glazbeno obrazovanje. ${ }^{12}$

Čimbenike koji utječu na glazbene preferencije može se kategorizirati na unutarnje i vanjske. Unutarnji se odnose na karakteristike glazbe, ${ }^{13}$ kao što su struktura, melodija, boja ${ }^{14} \mathrm{i}$ tempo. Utvrđeno je da tempo glazbe ima značajnu ulogu u formiranju glazbenih preferencija. ${ }^{15}$ Vanjski čimbenici koji utječu na glazbene preferencije mogu biti osobnost, društveni utjecaj, ${ }^{16}$ dob, spol, glazbeno obrazovanje, znanje, iskustvo, ${ }^{17}$ društveni identitet, glazbena industrija, kulturno okruženje, situacijski kontekst, emocionalne potrebe,$^{18}$ prihod, zanimanje, bračni status i političke sklonosti pojedinca. ${ }^{19}$

\section{Glazbene preferencije djece $i$ mladih}

Kod mlađe djece postoji otvorenost prema novim glazbenim stilovima koja postupno opada odrastanjem, tj. otvorenost nestaje u dobi od oko devet godina. Što se tiče glazbenog obrazovanja, prve godine osnovne škole kao i predškolski odgoj trebalo bi iskoristiti za mnogo glazbenih iskustava da bi se djeca upoznala s različitom glazbom. Naime, što su djeca mlađa to su otvorenija za umjetnič-

\footnotetext{
${ }^{9}$ Usp. Thomas SCHÄFER, The Goals and Effects of Music Listening and Their Relationship to the Strength of Music Preference, PloS one, 11 (2016) 3, e0151634, https://journals.plos.org/ plosone/article?id=10.1371/journal.pone.0151634 (17.03.2016).

${ }^{10}$ Usp. Adrian C. NORTH, David J. HARGREAVES, Musical preferences during and after relaxation and exercise, The American journal of psychology, 113 (2000) 1, 43-67, 65.

${ }^{11}$ Usp. Peter J. RENTFROW, Lewis R. GOLDBERG, Daniel J. LEVITIN, The structure of musical preferences. A five-factor model, Journal of personality and social psychology, 100 (2011) 6, 1139-1157, 1155.

${ }^{12}$ Usp. Durgesh K. UPADHYAY, Music Engagement, Music Preferences and Functions of Music Listening, International Journal of Social Science and Humanity, 3 (2013) 3, 287-291, 12.

${ }^{13}$ Usp. Lawendowski, Temporal Stability of Music Preferences..., 43.

${ }^{14}$ Usp. Meyers, Influences on Music Preference..., 31.

${ }^{15}$ Usp. Amanda P. MONTGOMERY, Effect of Tempo on Music Preferences of Children in Elementary and Middle School, Journal of Research in Music Education, 44 (1996) 2, 134-46, 134.

${ }^{16}$ Usp. Meyers, Influences on Music Preference..., 31.

${ }^{17}$ Usp. Hargreaves i sur., Musical preference and taste..., 135.

${ }^{18}$ Usp. Lawendowski, Temporal Stability of Music Preferences..., 24.

${ }^{19}$ Usp. Charlotta MELLANDER i dr., The geography of music preferences, Journal of Cultural Economics, 42 (2018) 4, 593-618, 612.
} 
ku i tradicijsku glazbu, dok odrastanjem ove vrste glazbe manje prihvaćaju. ${ }^{20}$ Otvorenost prema različitim stilovima se smanjuje do ulaska u adolescenciju, zatim se povećava ulaskom u mlađu odraslu dob te se opet smanjuje kako osoba ulazi u stariju dob. ${ }^{21}$ Stoga djecu treba od najranije dobi okružiti kvalitetnim i raznovrsnim glazbenim ostvarenjima ${ }^{22}$ da bi se uspostavila vrijednosna mjerila za estetsko i kritičko doživljavanje i procjenjivanje glazbe te se kod učenika razvio glazbeni ukus. ${ }^{23}$ Naime, djeca mlađe školske dobi mogu donijeti emocionalne i estetske prosudbe o nepoznatim glazbenim djelima. ${ }^{24}$

Odgoj i obrazovanje oblikuju, usmjeravaju i proširuju preferencije prema umjetničkoj glazbi, odnosno glazbena naobrazba utječe na veću preferenciju prema umjetničkoj glazbi u odnosu na pojedince koji takvu glazbu nisu imali priliku upoznati u okviru svog školovanja. ${ }^{25}$ Glazbeno obrazovanje je u pozitivnoj korelaciji s preferencijom umjetničke glazbe. ${ }^{26}$ Stoga ne čudi da djeca koja pjevaju u pjevačkom zboru iskazuju veći stupanj sviđanja prema umjetničkoj glazbi kao kategoriji koja je temelj poučavanja u nastavi glazbe, a koja je znatno manje prisutna u medijima i u svakodnevnom životu učenika u odnosu na ostale vrste glazbe. U aktivnostima zborskog pjevanja sustavno se djeluje na glazbene preferencije te se utječe na formiranje stavova o estetski vrijednoj glazbi. ${ }^{27}$ Glazba je važna u životu mladih jer im pomaže u svakodnevnom izražavanju osjećaja ${ }^{28}$ i poboljšanju cjelokupnoga psihičkog zdravlja. ${ }^{29}$ Razgovor o glazbenim preferencijama popularna je tema pri upoznavanju. Rezultati istraživanja koje su proveli Rentfrow i Gosling ${ }^{30}$ kazuju da je više od polovice mladih

${ }^{20}$ Usp. Heiner GEMBRIS, Gabriele SCHELLBERG, u: Reinhard KOPIEZ i dr. (ur.), Abstracts of the $5^{\text {th }}$ Triennial Conference of the European Society for the Cognitive Sciences of Music (ESCOM), Hannover, University of Music and Drama, 2003, 324.

${ }^{21}$ Usp. Albert LEBLANC, The development of music preference in children, u: Craig J. PEERY, Irene WEISS PEERY, Thomas W. DRAPER (ur.), Music and child development, New York, Springer-Verlag, 1987, 137-157, 151.

${ }^{22}$ Usp. Snježana DOBROTA, Kristina TOPIĆ, Glazbene preferencije učenika prema glazbama svijeta i hrvatskoj tradicijskoj glazbi, Školski vjesnik, 67 (2018) 2, 199-208, 206.

${ }^{23}$ Usp. Jasna ŠULENTIĆ BEGIĆ, Amir BEGIĆ, Ivana PUŠIĆ, Preferencije učenika prema aktivnostima i sadržajima u nastavi Glazbene kulture, Nova prisutnost, 18 (2020) 1, 185-202, 192.

${ }^{24}$ Usp. Sirke NIEMINEN i dr., The Development of the Aesthetic Experience of Music. Preference, Emotions, and Beauty, Musicae Scientiae, 16 (2012) 3, 372-391, 388.

${ }^{25}$ Usp. Tihana ŠKOJO, Glazbene preferencije učenika kao polazište za realizaciju izvannastavnih aktivnosti u strukovnim školama, Život i škola, 17 (2016) 2, 167-184, 182.

${ }^{26}$ Usp. Miranda Poh Khoon YEOH, Music Preferences of Teenage Students in Relation to Listener Psychology and Environmental Influences, disertacija, Sveučilište Putra Malezija, 2002, 3.

${ }^{27}$ Usp. Antoaneta RADOČAJ-JERKOVIĆ, Tihana ŠKOJO, Majda MILINOVIĆ, Zborsko pjevanje kao oblik neformalnog učenja i njegov utjecaj na formiranje dječjih glazbenih preferencija, Školski vjesnik, 67 (2018) 2, 311-329, 311.

${ }^{28}$ Usp. Oswaldo LORENZO-QUILES, João F. SOARES-QUADROS Jr., Johanna E. ABRIL, Musical preferences of Brazilian high school students, PLoS ONE, 15 (2020) 9, 0239891, https:// journals.plos.org/plosone/article?id=10.1371/journal.pone.0239891 (30.09.2020).

${ }^{29}$ Usp. Magdalena CHĘĆ, Ernest TYBURSKI, Agnieszka SAMOCHOWIEC, Music preferences and disordered functioning in adolescence, Psychiatria, 11 (2014) 4, 197-202, 197.

${ }^{30}$ Usp. Peter J. RENTFROW, Samuel D. GOSLING, Message in a ballad the role of music preferences in interpersonal perception, Psychological Science, 17 (2006) 3, 236-242, 237. 
prilikom upoznavanja na internetu razgovaralo o glazbi tijekom prvog tjedna, a glazba je ostala jedna od najpopularnijih tema tijekom njihove šestotjedne komunikacije. Boer i sur. ${ }^{31}$ utvrdili su da su za socijalno zbližavanje mladih važnije zajedničke glazbene preferencije nego osobine ličnosti. Glazbene preferencije su važne i odraslim osobama jer im služe kao statusni simbol, odnosno simbol društvenog identiteta. ${ }^{32}$

Glazba koju osobe slušaju u kasnoj adolescenciji i ranoj odrasloj dobi najviše se pamti u srednjoj i starijoj dobi, ${ }^{33}$ tj. preferencije prema glazbenim stilovima koji su popularni ili prisutni tijekom adolescencije i mlađe odrasle dobi održavaju se i kasnije tijekom života. Može se reći da su adolescencija i mlađa odrasla dob formativne faze za razvoj glazbenih preferencija. ${ }^{34}$ Adolescenti najviše preferiraju popularnu glazbu. ${ }^{35}$ Sklonost mladih prema alternativnoj i heavy metal glazbi vjerojatno je odraz buntovnog raspoloženja prema svim vrstama autoriteta. Ova glazba bliska je mladima zbog brzih i glasnih zvukova gitara i bubnjeva koji izražavaju različite emocije bliske mladim ljudima. Osim toga, tekstovi glazbenih stilova poput heavy metala ili alternativne glazbe bliski su adolescentima. Djevojke, u odnosu na mladiće, više preferiraju različite glazbene stilove, ${ }^{36}$ odnosno radije slušaju glazbu koja pobuđuje emocije i u kojoj je naglašena melodija. ${ }^{37}$ Također, djevojke su više sklone polaganoj i popularnoj glazbi, dok mladići više vole sofisticirane i ritmične glazbene stilove. ${ }^{38}$ Među glazbeno obrazovanim adolescentima najomiljenija je rock glazba iza koje slijede umjetnička i pop glazba. ${ }^{39}$

Iz svega navedenog može se zaključiti da su glazbene preferencije mladih, ali i preferencije odraslih, povezane s dobi, obitelji, vršnjacima, obrazovanjem, kulturnim okruženjem, spolom i stilom, tj. karakteristikama glazbe. Navedene spoznaje bile su polazište za istraživanje koje je provedeno u okviru ovoga rada.

${ }^{31}$ Usp. Diana BOER i dr., How shared preferences in music create bonds between people. Values as the missing link, Personality $\mathcal{E}$ social psychology bulletin, 37 (2011) 9, 1159-1171, 1166.

${ }^{32}$ Usp. Arielle BONNEVILLE-ROUSSY, John RUST, Age Trends in Musical Preferences in Adulthood. 2. Sources of Social Influences as Determinants of Preferences, Musicae Scientiae, 22 (2018) 2, 175-195, 191.

${ }^{33}$ Usp. Steve M. J. JANSSEN, Antonio G. CHESSA, Jaap M. J. MURRE, Temporal distribution of favourite books, movies, and records: Differential encoding and re-sampling, Memory, 15 (2007) 7, 755-767, 763.

${ }^{34}$ Usp. Tom F. M. ter BOGT i dr., Intergenerational Continuity of Taste. Parental and Adolescent Music Preferences, Social Forces, 90 (2011) 1, 297-319, 297.

${ }^{35}$ Usp. Yeoh, Music Preferences of Teenage Students..., 3.

${ }^{36}$ Usp. Ina REIĆ ERCEGOVAC, Snježana DOBROTA, Povezanost između glazbenih preferencija, sociodemografskih značajki i osobina ličnosti iz petfaktorskoga modela, Psihologijske teme, 20 (2011) 1, 47-65, 56.

${ }^{37}$ Usp. Upadhyay i sur., Factor Structure of Music Preference..., 113.

${ }^{38}$ Usp. Lorenzo-Quiles i sur., Musical preferences of Brazilian..., 11.

${ }^{39}$ Usp. Davor BRĐANOVIĆ, Glazbene preferencije učenika srednje glazbene škole, Napredak, 154 (2014) 1-2, 47-64, 47. 


\section{Istraživanje}

\subsection{Istraživački cilj i hipoteza}

Cilj istraživanja bio je utvrditi postoji li povezanost glazbenih preferencija učenika osnovne glazbene škole i spola, mjesta stanovanja i obiteljske glazbene tradicije. Istraživanje je polazilo od sljedeće hipoteze: Postoji statistički značajna povezanost sociodemografskih varijabla (spol učenika, mjesto stanovanja i bavljenje njihovih roditelja glazbom) i glazbenih preferencija učenika osnovne glazbene škole.

\subsection{Metoda istraživanja}

\subsubsection{Uzorak i postupak prikupljanja podataka}

Istraživanje je provedeno anketiranjem u travnju 2020. godine u sedam osnovnih glazbenih škola u Republici Hrvatskoj, tj. u tri osnovne glazbene škole na području grada Zagreba, osnovnoj glazbenoj školi u Osijeku, osnovnoj glazbenoj školi u Belom Manastiru, osnovnoj glazbenoj školi u Slatini i osnovnoj glazbenoj školi u Zaprešiću. U istraživanju je sudjelovalo 95 učenika petih i šestih razreda osnovnih glazbenih škola. Detaljniji opis uzorka nalazi se u tablici 1.

Tablica 1. Opis uzorka učenika

\begin{tabular}{|c|c|c|c|}
\hline \multirow{2}{*}{ Varijabla } & \multirow{2}{*}{ Kategorije } & \multicolumn{2}{|c|}{ Učenici (N=95) } \\
\cline { 3 - 4 } & & $\mathbf{f}^{*}$ & $\mathbf{\%}$ \\
\hline \multirow{2}{*}{ Spol } & Muški & 30 & 31,6 \\
& Ženski & 65 & 68,4 \\
\hline \multirow{2}{*}{ Razred } & Peti & 50 & 52,6 \\
& Šesti & 45 & 47,4 \\
\hline \multirow{2}{*}{ Mjesto stanovanja } & Grad & 76 & 80,0 \\
& Selo & 19 & 20,0 \\
\hline
\end{tabular}

*f-frekvencija (broj) ispitanika

Kao što je vidljivo iz tablice 1 , $\mathrm{u}$ anketiranju je sudjelovao veći broj ispitanika ženskog spola. S obzirom na razred podjednak broj ispitanika bio je iz petog i šestog razreda. I konačno, više učenika živi u gradu, a manje u seoskom području. 


\subsubsection{Instrument istraživanja}

Anonimni anketni upitnik bio je $\mathrm{u}$ online formatu te su ga učenici tako i ispunili. Njime su se htjela doznati sociodemografska obilježja učenika osnovne glazbene škole te njihove glazbene preferencije. Anketni upitnik je osmišljen izvorno na temelju analize literature i iskustva autora rada. Upitnik se sastojao od 22 pitanja od kojih su 8 bila dihotomnog karaktera (primjer: Slušaš li neku pjesmu samo zato jer je popularna - Da/Ne). Nadalje, upitnik je sadržavao i 10 pitanja višestrukog izbora (primjer: Po tvom mišljenju, tko/što najviše utječe na tvoj odabir glazbe? - a) Obitelj; b) Prijatelji; c) Internet; d) Glazbena škola; e) Nitko; f) Netko drugi). Četiri pitanja višestrukog izbora bila su u formi Likertove skale (primjer: Na ljestvici od 1 do 5 označi koliko ti se sviđa umjetnička glazba, gdje 1 znači da ti se uopće ne sviđa, 2 da ti se donekle ne sviđa, 3 niti svida, niti ne svida, 4 da ti se donekle svida, a 5 da ti se jako svida).

\subsubsection{Statistički postupci}

Za obradu kvantitativnih podataka korišten je hi-kvadrat test radi utvrđivanja mogućih statistički značajnih razlika u glazbenim preferencijama između učenika s obzirom na različite sociodemografske varijable. Kvantitativni podatci obrađeni su računalnim programom SPSS.

\subsection{Rezultati i rasprava}

Radi provjere hipoteze koja je glasila: Postoji statistički značajna povezanost sociodemografskih varijabla (spol učenika, mjesto stanovanja i bavljenje njihovih roditelja glazbom) i glazbenih preferencija učenika osnovne glazbene škole - uspoređeni su dobiveni rezultati. S obzirom na spol uočene su neke razlike (tablice 2 i 3).

Tablica 2. Uloga sociodemografskih varijabli u odabiru glazbe: rezultati prema spolu ispitanika

\begin{tabular}{|c|c|c|c|c|c|c|c|c|c|c|c|c|}
\hline \multirow{3}{*}{$\begin{array}{c}\text { Pitanje } \\
\text { Spol }\end{array}$} & \multicolumn{12}{|c|}{ Tko/što najviše utječe na tvoj odabir glazbe? } \\
\hline & \multicolumn{2}{|c|}{ obitelj } & \multicolumn{2}{|c|}{ prijatelji } & \multicolumn{2}{|c|}{ internet } & \multicolumn{2}{|c|}{$\begin{array}{c}\text { glazbena } \\
\text { škola } \\
\end{array}$} & \multicolumn{2}{|c|}{ nitko } & \multicolumn{2}{|c|}{ ostalo } \\
\hline & f & $\%$ & f & $\%$ & f & $\%$ & f & $\%$ & f & $\%$ & $\mathbf{f}$ & $\%$ \\
\hline $\begin{array}{c}\text { muški } \\
(\mathrm{N}=30)\end{array}$ & 1 & 3,3 & 0 & 0 & 10 & 33,3 & 3 & 10 & 15 & 50 & 1 & 3,3 \\
\hline $\begin{array}{l}\text { ženski } \\
(\mathrm{N}=65)\end{array}$ & 9 & 17,2 & 15 & 23,1 & 7 & 10,8 & 2 & 3,1 & 30 & 46,2 & 2 & 3,1 \\
\hline
\end{tabular}

Odgovori na pitanje Tko/što najviše utječe na tvoj odabir glazbe? pokazuju da polovica muških i ženskih ispitanika smatra da nitko nema presudan utjecaj 
na odabir glazbe koju slušaju. Ponuđeni odgovori bili su: obitelj, prijatelji, internet, glazbena škola, nitko i netko drugi. Ovaj rezultat bi se mogao objasniti činjenicom da se u toj dobi mladi već smatraju »odraslima« i da nisu ni pod čijim utjecajem. Međutim, čak 15 učenica je izjavilo da prijatelji najviše utječu na njihov odabir, dok nijedan učenik nije toga stava. Uvjereni smo da vršnjaci zasigurno utječu na preferencije mladih jer adolescenti na svoje glazbene preferencije gledaju kao na sredstvo koje ih povezuje s vršnjacima koji imaju iste preferencije. Ujedno pretpostavljamo da muški ispitanici toga nisu svjesni onoliko koliko djevojke jesu. Isto tako, devet učenica i samo jedan učenik smatraju da je najsnažniji utjecaj obitelji, što ne iznenađuje, jer roditelji mogu oblikovati glazbeni ukus svoje djece tako da ih uvjere u vrijednost glazbe koju zajedno slušaju ili pjevaju. ${ }^{40}$ Što se tiče utjecaja interneta i glazbene škole na odabir glazbe, učenice smatraju da su manje podložne utjecaju interneta i glazbene škole nego što to smatraju muški ispitanici.

Tablica 3. Sviđanje rock i metal glazbe s obzirom na spol

\begin{tabular}{|c|c|c|c|c|c|}
\hline \multirow{3}{*}{ Pitanje } & \multicolumn{4}{|c|}{ Spol } & \multirow{3}{*}{$\chi^{2}$} \\
\hline & \multicolumn{2}{|c|}{ Muški $(\mathrm{N}=30)$} & \multicolumn{2}{|c|}{ Ženski $(\mathrm{N}=65)$} & \\
\hline & f & $\%$ & f & $\%$ & \\
\hline Koji glazbeni stil ti se najviše sviđa? (rock) & 3 & 10 & 19 & 29,2 & 4,27 * \\
\hline Koji glazbeni stil ti se najviše sviđa? (metal) & 7 & 23,3 & 0 & 0 & 16,37 ** \\
\hline
\end{tabular}

*** $p<0,01 ; * p<0,05$

U sljedećem pitanju učenici su trebali zaokružiti glazbene stilove koji im se sviđaju. Ponuđeni odgovori bili su: umjetnička glazba, pop, rock, metal, hiphop, punk, turbofolk, funk, rap, reggae, jazz, elektronička glazba, filmska glazba i glazba iz video igara i nešto drugo. Znatno više učenica $(\mathrm{N}=19)$ odlučilo se za rock stil, naspram dječaka $(\mathrm{N}=3)$ i slijedom toga je hi-kvadrat testom (tablica 3) utvrđena statistički značajna razlika $(p=0,04)$. Također, s obzirom na preferencije prema metal glazbi došlo se do podatka da sedam učenika preferira navedeni glazbeni stil dok se nijedna učenica nije pozitivno izjasnila $(p=0,002)$. Ovi rezultati su djelomično u skladu s jednim drugim istraživanjem koje je pokazalo da je muški spol skloniji heavy metal, ali i rock glazbi, za razliku od ženskog spola. ${ }^{41}$

Nadalje, utvrđena je statistički značajna razlika u dvije varijable s obzirom na mjesto stanovanja (tablica 4).

\footnotetext{
${ }^{40}$ Usp. Bogt i sur., Intergenerational Continuity of Taste..., 315.

${ }^{41}$ Usp. Snježana DOBROTA, Ina REIĆ ERCEGOVAC, Katarina HABE, Gender Differences in Musical Taste. The Mediating Role of Functions of Music, Društvena istraživanja, 28 (2019) 4, 567-586, 573.
} 
Tablica 4. Razlike s obzirom na mjesto stanovanja

\begin{tabular}{|c|c|c|c|c|c|}
\hline \multirow{3}{*}{ Tvrdnja } & \multicolumn{4}{|c|}{ Mjesto stanovanja } & \multirow{3}{*}{$\chi^{2}$} \\
\hline & \multicolumn{2}{|c|}{ Grad $(N=76)$} & \multicolumn{2}{|c|}{ Selo $(\mathrm{N}=19)$} & \\
\hline & f & $\%$ & $\mathbf{f}$ & $\%$ & \\
\hline Sviđa mi se turbofolk & 6 & 7,9 & 5 & 26,3 & $5,04 *$ \\
\hline Zadane skladbe preslušavam kod kuće & 44 & 57,9 & 5 & 26,3 & $6,07^{*}$ \\
\hline
\end{tabular}
" $p<0,05$

Kao što se može vidjeti iz tablice 4, oko četvrtine učenika iz sela preferira turbofolk glazbu, za razliku od učenika iz grada (manje od $8 \%$ ). Osim preferencija prema navedenom stilu uočena je razlika između ispitanika s obzirom na pitanje: Slušaš li kod kuće skladbe koje sviraš u glazbenoj školi jer ti se sviđaju? Naime, više od polovice učenika koji žive u gradu u slobodno vrijeme sluša skladbe koje sviraju u glazbenoj školi, dok to čini svega četvrtina učenika koji žive na seoskom području $(p<0,05)$. Ovaj rezultat pomalo iznenađuje jer je bilo očekivano da neće biti statistički značajnije razlike. Možda je razlog u nedostatku slobodnog vremena učenika koji žive na seoskom području s obzirom na vrijeme potrebno za odlazak i dolazak u općeobrazovnu i glazbenu školu.

Naposljetku, uspoređeni su odgovori ispitanika s obzirom na to bavi li se ili se bavio glazbom netko u njihovoj obitelji. Statistički značajna razlika uočena je samo s obzirom na odlaske na koncerte umjetničke i popularne glazbe i preferencije prema pop i elektroničkoj glazbi (tablica 5).

Tablica 5. Razlike s obzirom na glazbenu tradiciju u obitelji

\begin{tabular}{|c|c|c|c|c|c|}
\hline \multirow{3}{*}{ Pitanje } & \multicolumn{4}{|c|}{ Glazbena tradicija u obitelji } & \multirow{3}{*}{$\chi^{2}$} \\
\hline & \multicolumn{2}{|c|}{ Da } & \multicolumn{2}{|c|}{$\mathrm{Ne}$} & \\
\hline & f & $\%$ & f & $\%$ & \\
\hline Odlaziš li na koncerte umjetničke glazbe? & 43 & 76,8 & 22 & 56,4 & $4,53^{\text {**** }}$ \\
\hline Odlaziš li na koncerte popularne glazbe? & 36 & 64,3 & 15 & 38,5 & $12,60 *$ \\
\hline Voliš li slušati pop glazbu? & 52 & 92,9 & 26 & 66,7 & $4,30 *$ \\
\hline Voliš li slušati elektroničku glazbu? & 2 & 3,6 & 6 & 15,4 & $9,79 *$ \\
\hline
\end{tabular}

*** $p<0,01 ; " p<0,05$

Iz tablice 5 vidljivo je da više od tri četvrtine učenika koji u obitelji imaju nekoga tko se bavio ili se bavi glazbom posjećuje koncerte umjetničke glazbe, dok to čini nešto više od polovice učenika koji u obitelji nemaju glazbenu tradiciju $(p=0,009)$. Ovakav rezultat je bio očekivan s obzirom da glazbena tradicija u obitelji sigurno motivira mlade na bavljenje glazbom pa samim time i na odlaske na glazbene događaje. Roditelji žele sa svojom djecom podijeliti svoje oduševljenje umjetnicima, bendovima ili skladateljima, što rezultira međugeneracijskim sličnostima. ${ }^{42}$ Stoga $u$ ranoj fazi izgradnje (glazbenog) identiteta

${ }^{42}$ Usp. Bogt i sur., Intergenerational Continuity of Taste..., 315. 
ne treba zanemariti utjecaj obitelji. ${ }^{43}$ Isti je slučaj i s odlascima na koncerte $p o p$ glazbe $(p=0,03)$. Ujedno, učenici s glazbenom tradicijom u obitelji više preferiraju pop glazbu $(p=0,01)$, a učenici bez obiteljske glazbene tradicije elektroničku glazbu $(p=0,04)$.

Dakle, istraživačka hipoteza koja je glasila: Postoji statistički značajna povezanost sociodemografskih varijabla (spol učenika, mjesto stanovanja i bavljenje njihovih roditelja glazbom) i glazbenih preferencija učenika osnovne glazbene škole - djelomično je prihvaćena.

\section{Zaključak}

Treba imati u vidu da su mladi i djeca sve napredniji u korištenju tehnologije, ${ }^{44}$ što im omogućuje jednostavan doticaj s glazbom na internetu. Tako su od najranije dobi izloženi različitim stilovima glazbe. Također, izloženi su različitim načinima slušanja glazbe koje je najčešće pasivno i prati televizijske programe, internetske stranice, filmove i igranje igara. ${ }^{45}$ Masovni mediji u današnjem društvu glavni su izvor informacija i zabavnih sadržaja, a imaju cilj privući što veći broj korisnika. ${ }^{46}$ Navedene činjenice učitelji glazbe trebali bi imati u vidu u nastavi i biti kreativni i domišljati pri oblikovanju nastavnih sadržaja i aktivnosti. S obzirom na važnost glazbe u životu mladih ljudi i njezinu veliku prisutnost u svakodnevnom životu, uporaba različitih stilova glazbe u nastavi glazbe učinit će nastavu glazbe učenicima zanimljivijom ${ }^{47}$ te će se povećati motivacija učenika za učenjem. Iako učitelji najčešće ne mogu utjecati na društvene i okolišne čimbenike povezane s razvojem glazbenih preferencija, oni te preferencije ipak mogu oblikovati odabirom glazbenih primjera koje će koristiti u nastavi, imajući u vidu da ti primjeri sadrže glazbene karakteristike koje se sviđaju učenicima. ${ }^{48}$

Ovim se radom htjelo utvrditi postoje li razlike između glazbeno obrazovanih adolescenata, $t j$. učenika petih i šestih razreda osnovne glazbene škole $u$ glazbenim preferencijama s obzirom na različite sociodemografske varijable. Ujedno, htjeli su se doznati stavovi ispitanika o vanjskim utjecajima na vlastite preferencije. Rezultati su pokazali da polovica muških i ženskih ispitanika

\footnotetext{
${ }^{43}$ Usp. Filip TRBOJEVIĆ, Kulturni kapital mladih: preferencije i transmisija popularnih glazbenih žanrova među studentima Sveučilišta u Zagrebu, Medijska istraživanja, 25 (2019) 2, 45-67, 62.

${ }^{44}$ Usp. Anna LEASK, Alan FYALL, Paul BARRON, Generation Y. An agenda for future visitor attraction research, International Journal of Tourism Research, 16 (2014) 462-471, 468.

${ }^{45}$ Usp. Kathryn ROULSTON, Qualitative investigation of young children's music preferences, International Journal of Education \& the Arts, 7 (2006) 9, 1-24, 12.

${ }^{46}$ Usp. Katica KNEZOVIĆ, Iva MAKSIMOVIĆ, Manipulativna moć masovnih medija i etičke upitnosti njihova utjecaja na dijete, Diacovensia, 24 (2016) 4, 645-666, 646.

${ }^{47}$ Usp. North, Hargreaves, Musical preferences during..., 48.

${ }^{48}$ Usp. Yeoh, Music Preferences of Teenage Students..., 3.
} 
smatra da nitko nema presudan utjecaj na odabir glazbe koju slušaju. Približno četvrtina učenica je izjavila da prijatelji najviše utječu na njihov odabir, dok nijedan učenik nije toga stava. Što se tiče utjecaja interneta i glazbene škole, učenice smatraju da su manje podložne njihovu utjecaju nego što to smatraju muški ispitanici. Nadalje, utvrđeno je da među ispitanicima postoje statistički značajne razlike $u$ preferencijama prema nekim vrstama i stilovima glazbe $s$ obzirom na spol. Gotovo trećina učenica preferira rock stil, za razliku od svakog desetog dječaka. Četvrtina učenika preferira metal glazbu dok se nijedna učenica nije potvrdno izjasnila. Statistički značajne razlike u preferencijama među učenicima utvrđene su i s obzirom na mjesto stanovanja i glazbenu tradiciju u obitelji. Približno četvrtina učenika iz sela preferira turbofolk glazbu, za razliku od dvanaestine učenika iz grada. Više od polovice učenika koji žive u gradu u slobodno vrijeme sluša skladbe koje sviraju u glazbenoj školi, dok to čini svega četvrtina učenika koji žive na seoskom području. Otprilike tri četvrtine učenika koji u obitelji imaju nekoga tko se bavio ili se bavi glazbom odlazi na koncerte umjetničke glazbe, za razliku od polovice učenika koji u obitelji nemaju glazbenu tradiciju. Sličan odnos utvrđen je i s obzirom na odlaske na koncerte pop glazbe. Ujedno, gotovo svi učenici s glazbenom tradicijom u obitelji preferiraju pop glazbu, naspram dvije trećine učenika bez obiteljske tradicije. Otprilike šestina učenika bez obiteljske glazbene tradicije preferira elektroničku glazbu za razliku od svega dva učenika s tradicijom u obitelji.

Istraživanje koje bi, osim učenika glazbene škole, uključilo i učenike završnih razreda osnovne općeobrazovne škole, dalo bi potpuniji uvid u povezanost sociodemografskih varijabla i glazbenih preferencija ispitanika. Adolescencija je vrijeme značajnih razvojnih promjena, formiranja identiteta i osobnosti, a sve navedene promjene intenzivno prati glazba. Također, treba imati u vidu da mladi koji imaju višu glazbenu naobrazbu pokazuju više poštovanja prema različitim vrstama i stilovima glazbe te stoga imaju manje definirane glazbene identitete, čime se pokazuje velik utjecaj kulturnog okruženja u kojem se živi. ${ }^{49}$ Stoga je važno da učitelji glazbe kompetentno i odgovorno razvijaju kritičko mišljenje svojih učenika i tako (ne)posredno utječu na oblikovanje njihovih glazbenih preferencija i, u konačnici, glazbenog ukusa.

\footnotetext{
${ }^{49}$ Usp. Roman SUAREZ CANEDO, Students' Musical Preferences and Music Analysis Learning in Secondary Education, International Journal for Cross-Disciplinary Subjects in Education (IJCDSE), 3 (2013) 2, 1472-1476, 1475.
} 


\section{Jasna Šulentić Begić* - Amir Begić"**: Marija Bilić**** \\ Relationship Between Sociodemographic Variables and Musical Preferences of Elementary Music School Students \\ Summary}

The preferences are defined as an effective low-intensity state, which concerning the music field would mean music by a musician or a certain musical style or a specific composition that an individual likes and chooses to listen to. Music preferences are usually a spontaneous reaction and do not necessarily include aesthetic criteria, i.e. cognitive processes. Factors that are related to musical preferences can be categorized as internal (e.g., music characteristics) and external (e.g., age, gender, personality, social influence, music education, social identity, etc.). In this paper a study was conducted aimed at determining the relationship between sociodemographic variables (gender of students, place of residence and their parents' involvement in music) and musical preferences of primary music school students. The survey was conducted by an online survey in April 2020 in seven primary music schools in Republic of Croatia. The study involved 95 fifth-and sixth-grade elementary music school students. Using the Hi-square test, the existence of statistically significant differences in the respondents' preferences towards rock, metal, turbo-folk, art, pop and electronic music with regard to gender, place of residence and musical tradition in the family was determined.

Key words: musical preferences, music teaching, elementary music school.

(na engl. prev. Amir Begić)

* Jasna Šulentić Begić, PhD, Assoc. Prof., Josip Juraj Strossmayer University of Osijek, The Academy of Arts and Culture in Osijek; Address: Kralja Petra Svačića 1/F, HR-31000 Osijek, Croatia; E-mail: jsulentic-begic@aukos.hr.

** Amir Begić, PhD, Assist. Prof., Josip Juraj Strossmayer University of Osijek, The Academy of Arts and Culture in Osijek; Address: Kralja Petra Svačića 1/F, HR-31000 Osijek, Croatia; Email: abegic@aukos.hr.

***: Marija Bilić, mag. mus., Music School Music Atelier; Address: Harambašićeva 14, HR-10000 Zagreb, Croatia; E-mail: marijabilicv@gmail.com. 